\title{
EFFICACY OF SOME ALGAL SPECIES, AZOLLA AND COMPOST EXTRACT IN CONTROLLING ROOT KNOT NEMATODE AND ITS REFLECTION ON CUCUMBER GROWTH
}

\author{
(Received: 1.7.2009)
}

\author{
By \\ S. M. Shawky , S. S. M. Mostafa* and A. A. M. Abd El-All * \\ Nematode Research Department, Plant Pathology Research. Institute Agricultural Research Center, \\ Giza, Egypt \\ *Microbiol. Department, Soils, Water \& Environment. Research Institute (SWERI), Agricultural \\ Research Center (ARC), Giza, Egypt
}

\begin{abstract}
This study aimed to use nine culture filtrates of algal strains (Nostoc muscorum, Anabaena flos aquae, Anabaena oryzae, Chlorella vulgaris, Wollea saccata, Phormedium fragile, Oscillatoria sp., Nostoc humifusum and Spirulina platensis), Azolla pinnata aqueous extract filtrate $(1: 2 \mathrm{w} / \mathrm{v})$ and compost watery extract filtrate $(1: 5 \mathrm{w} / \mathrm{v})$ in controlling the population of the root knot nematode, Meloidogyne incognita in cucumber under both laboratory and greenhouse conditions. Laboratory experiment revealed that high juvenile mortality percentage occurred during all the exposure periods of all treatments, the best results were after $72 \mathrm{hr}$ exposure. Only five cyanobacterial strains, namely, Spirulina platensis, Oscillatoria sp., Anabaena oryzae, Nostoc muscorum and Phormedium fragile, followed by compost watery extract, significantly increased juveniles mortality over $70 \%$ at the highest concentration of $1: 10(84.3,80.4,78.9,75.4,72.5$ and $70.1 \%$, respectively). Azolla pinnata aqueous extract filtrate achieved $69.8 \%$ at the same concentration while, Anabaena flos aquae and Chlorella vulgaris recorded the lowest effect on mortality percentage (52.1 and $40.1 \%$, respectively) at the concentration of $1: 10$. In the greenhouse experiment, the combination of mixing five algal culture filtrates of $S$. platensis, Oscillatoria sp., A. oryzae, N. muscorum and $P$. fragile with A. pinnata aqueous extract filtrate and compost extract achieved the highest reduction in the number of the $2^{\text {nd }}$ stage juveniles in soil, the numbers of galls, developmental stages, females, egg masses, egg numbers/egg mass in roots of cucumber plants comparing with the individual treatment and the non treated control. In addition, all combinations significantly improved fresh weight of roots and shoots and increased the yield of cucumber plants. The combined treatment of mixed algal culture filtrates $+A$. pinnata aqueous extract filtrate + compost extract significantly enhanced the soil biological activity in terms of total bacterial count, total cyanobacterial count, $\mathrm{CO}_{2}$ evolution, dehydrogenase and nitrogenase activities as well as the soil available nitrogen forms $\left(\mathrm{NH}_{4}^{+}, \mathrm{NO}_{3}^{--}\right.$and $\left.\mathrm{NO}_{2}^{--}\right)$, available phosphorus and potassium over the control and resulting in soil electrical conductivity (EC) and soil $\mathrm{pH}$ reduction. It could be recommended that application of bioorganic agents as nematicidal against root knot nematode in cucumber is preferable in order to reduce the soil and plant polluting chemical nematicides.
\end{abstract}

Key words: algal culture filtrates, azolla pinnata aqueous extract filtrate, compost watery extract, cucumber.

\section{INTRODUCTION}

Cucumber (Cucumis sativus L.) is a favorite commodity export for markets and local consumption and represents one of the most important and economic vegetables in Egypt. It is grown in Egypt in the open fields from March to November and under plastic houses from September to May (Bayoumi and Hafez, 2006). Root-knot nematodes, Meloidogyne spp., are among the most damaging nematodes in agriculture, causing an estimated US\$ 100 billion loss/year worldwide (Oka et al., 2000). Root-knot nematode is a serious malady and causes significant losses in cucumber yield if not treated with nematicides. After hatching from eggs, second-stage juveniles invade roots of host plants and migrate intercellularly to differentiating vascular regions. The symptoms of nematode infection are the formation of root galls which result in growth reduction, nutrients and water uptake reduction, wilting increase and mineral deficiency, resulting in weak and poor yielding plants (Abad et al., 2003). The application of chemical nematicides has been found as an effective measure for controlling nematodes but they have toxic residual effect on the environment 
particularly on non-target organisms and human health. In addition, the use of chemical nematicides is prohibited in organic farming. Therefore, there is an urgent need to develop alternative environmental safe strategies for controlling nematodes (Anastasiadis et al., 2008). During the last decades, research on nematode control was focused on proposing strategies for the inhibition of egg hatch (Westcott and Kluepfel, 1993), degradation of hatching factor (Oostendrop and Sikora, 1989) or production of metabolites (Meadows et al., 1989). Recently, one of the biological control practices attempted is the study of the nematicidal potential of cyanobacterial culture filtrates that parasitize plant-parasitic nematodes (Khan et al., 2005).

Blue-green algae (Cyanobacteria) are distributed world-wide and contribute to the fertility of many agricultural ecosystems, either as free-living organisms or in symbiotic association with the water-fern Azolla (Fay, 1983). Azolla, a dichotomously branched free floating aquatic fern, is naturally available mostly in the tropical belt of India. The dorsal lobe which remains exposed to air has a specific cavity containing its symbiotic partner, a blue green algae Anabaena azollae. Abundant growth of Azolla not only makes a useful addition of combined nitrogen to the ecosystem but can also provide a 'green manure'.

Cyanobacteria that excrete a great number of substances have been reported to benefit plants by producing growth-promoting regulators (PGPR), vitamins, amino acids, polypeptides, antibacterial and antifungal substances that exert phytopathogen biocontrol, and polymers, especially exopolysaccharides, that improve soil structure and exoenzyme activity (Zaccaro et al., 2001).

Nematicidal potential of Cyanobacteria has remained unexplored except for a few reports, which suggest that endospores of Microcoleus and Oscillatoria spp. killed nematodes (Dhanam et al., 1994). Culture filtrates of Microcoleus vaginatus inhibited hatching of Meloidogyne incognita eggs and killed second stage juveniles (Khan et al., 1997). Microalgal metabolites have attracted attention, because they are a resource for toxins, and potential new drugs (Shimizu, 2003).

Compost watery extract, generally defined as a liquid fertilizer, has gained acceptance by homeowners and commercial growers around the world for its ability to stimulate soil biological activity, improve soil structure, and enhance overall plant health and vigor. Reported benefits of using compost extract include enhanced disease suppression, reduced fungicide and fertilizer requirements and associated cost savings. Research efforts to validate these benefits are expanding. Compost extract affect soils, crops and the organic farming system, and have an important role in decreasing nematode population (El Gendy and Shawky, 2006).

This investigation aimed to evaluate the efficacy of algal culture filtrates, Azolla pinnata fresh biomass aqueous extract and compost watery extract on the root knot nematode Meloidogyne incognita activity in vitro under laboratory conditions to select the most promising results to be applied in controlling $M$. incognita in cucumber plants in greenhouses.

\section{MATERIALS AND METHODS \\ 2.1. Cyanobacteria and Azolla pinnata source and growth conditions}

Cyanobacteria strains (Anabaena flos aquae, Anabaena oryzae, Nostoc humifusum, Nostoc muscorum, Oscillatoria sp., Spirulina platensis, Phormedium fragile and Wollea saccata) and the green alga strains Chlorella vulgaris and Azolla pinnata were obtained from the Microbiology Department, Soils Water and Environment Res. Inst., ARC, Giza, Egypt. Cyanobacteria strains were maintained in BG11 medium (Rippka et al., 1979) except Spirulina platensis which was cultured in Zarrouk medium (Zarrouk, 1966), while Bold medium (Nichols and Bold, 1965) was used for the green alga Chlorella vulgaris. Cultures were incubated in a growth chamber under continuous illumination (2000 lux) and tempe- rature of $25{ }^{\circ} \mathrm{C} \pm 2{ }^{\circ} \mathrm{C}$ for all strains except the mesophilic alga Spirulina platensis (32 ${ }^{\circ} \mathrm{C} \pm 2{ }^{\circ} \mathrm{C}$ ). Azolla pinnata was grown on modified Yoshida medium (Yoshida et al., 1976).

\subsection{Preparation of algal culture filtrates and Azolla pinnata aqueous extract}

After 30 days of incubation, each algal biomass was separated from its culture medium by filtration. The growth parameters of algal cultures and chemical analyses of their filtrates were determined (Table 1). Azolla pinnata was harvested from the culture medium and mixed well with distilled water $(1: 2 \mathrm{w} / \mathrm{v})$ using an electric mixer, then filtered to obtain the fresh biomass aqueous extract. The chemical composition of Azolla pinnata fresh biomass and aqueous solution is presented in Table (2). The algal culture filtrates and Azolla fresh biomass aqueous extract (50\%) were kept at $4^{\circ} \mathrm{C}$ till used in laboratory and greenhouse experiments. 
Table (1): Algal growth parameters and chemical analyses of algal culture filtrates

\begin{tabular}{|c|c|c|c|c|c|c|c|c|c|}
\hline \multirow[t]{2}{*}{ Treatments } & $\begin{array}{c}\text { Nostoc } \\
\text { muscorum }\end{array}$ & $\begin{array}{c}\text { Anabaena } \\
\text { flous aquae }\end{array}$ & $\begin{array}{l}\text { Chlorella } \\
\text { vulgaris }\end{array}$ & $\begin{array}{c}\text { Oscillatoria } \\
\text { sp. }\end{array}$ & $\begin{array}{l}\text { Spirulina } \\
\text { platensis }\end{array}$ & $\begin{array}{c}\text { Anabaena } \\
\text { oryzae }\end{array}$ & $\begin{array}{l}\text { Wollea } \\
\text { saccata }\end{array}$ & $\begin{array}{c}\text { Nostoc } \\
\text { humifusum }\end{array}$ & $\begin{array}{l}\text { Phormedium } \\
\text { fragile }\end{array}$ \\
\hline & \multicolumn{9}{|c|}{ Cultures growth parameters } \\
\hline $\begin{array}{l}\text { pH } \\
\text { OD } \\
\text { Ch-a }\left(\mathrm{mgl}^{-1}\right) \\
\text { Dry weight }\end{array}$ & $\begin{array}{c}7.63 \\
1.16 \\
4.34 \\
744.32\end{array}$ & \begin{tabular}{c|}
6.61 \\
1.16 \\
1.78 \\
727.65
\end{tabular} & $\begin{array}{c}8.11 \\
1.611 \\
5.88 \\
1052.16\end{array}$ & $\begin{array}{c}5.82 \\
0.22 \\
4.80 \\
140.16\end{array}$ & $\begin{array}{c}10.48 \\
2.50 \\
23.45 \\
2622.40\end{array}$ & $\begin{array}{c}6.27 \\
1.76 \\
5.87 \\
1123.20\end{array}$ & \begin{tabular}{|c|}
6.11 \\
1.98 \\
14.25 \\
1267.84
\end{tabular} & $\begin{array}{c}8.70 \\
1.20 \\
5.23 \\
760.80\end{array}$ & $\begin{array}{c}9.33 \\
1.66 \\
2.86 \\
1062.40\end{array}$ \\
\hline Dry weight & \multicolumn{9}{|c|}{ Culture filtrates chemical analyses } \\
\hline \multirow[t]{2}{*}{$\begin{array}{l}\text { pH } \\
\text { Ec }\left(\mathrm{dSm}^{-1}\right)\end{array}$} & $\begin{array}{l}7.05 \\
0.20\end{array}$ & $\begin{array}{l}7.21 \\
0.60\end{array}$ & $\begin{array}{l}8.15 \\
1.09\end{array}$ & $\begin{array}{c}6.63 \\
32.00\end{array}$ & $\begin{array}{c}9.9 \\
19.29\end{array}$ & $\begin{array}{l}7.11 \\
0.72\end{array}$ & $\begin{array}{l}7.39 \\
0.47\end{array}$ & $\begin{array}{l}7.42 \\
0.24\end{array}$ & $\begin{array}{l}8.55 \\
0.18\end{array}$ \\
\hline & \multicolumn{9}{|c|}{ Available nutrients (ppm) } \\
\hline $\begin{array}{l}\mathrm{NH}_{4}{ }^{+}-\mathrm{N} \\
\mathrm{NO}_{3}--\mathrm{N} \\
\mathrm{NO}_{2}--\mathrm{N} \\
\mathrm{P} \\
\mathrm{K}\end{array}$ & \begin{tabular}{|c|c|}
14.63 & \\
24.40 & 1.09 \\
44.90 & \\
11.03 &
\end{tabular} & \begin{tabular}{|l|l|}
16.21 \\
41.56 \\
0.84 \\
0.75
\end{tabular} & \begin{tabular}{|c|c|}
9.87 \\
57.57 \\
1.26 \\
$\mathbf{3 8 . 4 2}$ \\
$\mathbf{7 7 . 5 5}$
\end{tabular} & \begin{tabular}{|c|}
10.99 \\
28.21 \\
2.10 \\
9.73 \\
13.23
\end{tabular} & $\begin{array}{c}1.71 \\
149.50 \\
5.05 \\
300.00 \\
652.90\end{array}$ & $\begin{array}{c}2.22 \\
21.73 \\
2.95 \\
0.50 \\
23.16\end{array}$ & \begin{tabular}{c|}
12.44 \\
47.28 \\
2.10 \\
3.49 \\
22.05
\end{tabular} & \begin{tabular}{|c|c|}
13.49 & \\
52.61 & 4.21 \\
19.21 & \\
12.86 &
\end{tabular} & \begin{tabular}{c|}
2.71 \\
35.08 \\
0.84 \\
4.99 \\
11.76
\end{tabular} \\
\hline
\end{tabular}

Table (2): Chemical composition of Azolla pinnata fresh biomass and aqueous extract

\begin{tabular}{|l|c|c|c|}
\hline \multicolumn{2}{|c|}{ Azolla pinnata fresh biomass } & $\mathrm{pH}$ & 7.84 \\
\hline Moisture \% & 93.6 & $\mathrm{Ec} \mathrm{ds} / \mathrm{m}$ & 2.75 \\
\hline Total nitrogen \% & 2.90 & Potassium (ppm) & 148.49 \\
\hline Total phosphorus \% & 0.80 & Phosphorus (ppm) & 26.76 \\
\hline Total potassium\% & 1.16 & Organic carbon (ppm) & 1628.68 \\
\hline Organic carbon \% & 16.88 & Organic matter (ppm) & 2808.00 \\
\hline Organic matter \% & 29.11 & $\mathrm{NH}_{4}^{+}-\mathrm{N}(\mathrm{ppm})$ & 4.432 \\
\hline Ash \% & 70.89 & $\mathrm{NO}_{3}^{--}-\mathrm{N}(\mathrm{ppm})$ & 35.08 \\
\hline C/N ratio & 5.83 & $\mathrm{NO}_{2}^{--}-\mathrm{N}(\mathrm{ppm})$ & 3.79 \\
\cline { 2 - 4 }
\end{tabular}




\subsection{Compost watery extract preparation}

Compost watery extract was prepared from compost suspended in water (1:5, v:v) for 7 days and supplied with aquarium pump for continuous aeration (Al-Dahmani et al., 2003). The complete biochemical and biological analyses for compost and its watery extract filtrate are presented in Table (3).

Table (3): Compost and compost watery extract (1:5) biochemical and biological analvses

\begin{tabular}{|c|c|c|}
\hline Characters & Compost & $\begin{array}{c}\text { Compost } \\
\text { extract }\end{array}$ \\
\hline Moisture \% & 21.00 & - \\
\hline pH (1:10) & 8.57 & 8.42 \\
\hline Ec ds.m ${ }^{-1}(1: 10)$ & 5.43 & 18.19 \\
\hline $\mathrm{N}-\mathrm{NH}_{4}{ }^{+}(\mathbf{p p m})$ & 480.00 & 35.0 \\
\hline $\mathrm{N}-\mathrm{NO}_{3}{ }^{--}(\mathbf{p p m})$ & 80.00 & 22.0 \\
\hline Total nitrogen \% & 1.53 & 0.012 \\
\hline Organic matter $\%$ & 37.60 & 0.052 \\
\hline Organic carbon $\%$ & 21.80 & 0.03 \\
\hline Ash\% & 62.40 & - \\
\hline $\mathrm{C} / \mathrm{N}$ ratio & 14.2 & 2.5 \\
\hline Total phosphorus\% & 0.29 & 0.04 \\
\hline Total potassium \% & 0.79 & 0.006 \\
\hline Coliform group (cfu) & nd & nd \\
\hline $\begin{array}{l}\text { Salmonella and } \\
\text { Shigella (cfu) }\end{array}$ & nd & nd \\
\hline Nematode & nd & nd \\
\hline
\end{tabular}

2.4. Efficacy of algal culture filtrates, Azolla pinnata aqueous extract filtrate and compost extract on the activity of Meloidogyne incognita juveniles under laboratory conditions

For studying the efficacy of the algal culture filtrates, Azolla pinnata aqueous extract and compost extract on Meloidogyne incognita juveniles in vitro, $1 \mathrm{ml}$ of each treatment at three concentrations (1:10,1:25, 1:50) of the prepared stock filtrates was added separately to $1 \mathrm{ml}$ of nematode suspension containing 100 juveniles in glass vials. The numbers of active and non-active juveniles were examined and counted microscopically after 24, 48 and 72 hours.

The following treatments were allocated:

1-Anabaena flos aquae 2-Anabaena oryzae

3-Chlorella vulgaris 4-Nostoc humifusum

5-Nostoc muscorum 6-Phormedium fragile

7-Oscillatoria sp. 8- Spirulina platensis

\section{9-Wollea saccata}

10- Azolla pinnata aqueous extract filtrate

11-Compost extract 12-Vydate (nematicide)

2.5. Efficacy of algal culture filtrates, Azolla pinnata aqueous extract filtrate and compost extract individually and/or in combination on cucumber infection by Meloidogyne incognita under greenhouse conditions

This experiment was conducted under greenhouse conditions at Giza Governorate (Gezerat El Dahab) during the summer season of 2008. The soil texture was clay loamy, soil $\mathrm{pH}$ in water suspension (1:2.5) was 7.68 and $\mathrm{EC}$ of soil paste at $25^{\circ} \mathrm{C}$ was $1.53 \mathrm{ds} \cdot \mathrm{m}^{-1}$ (AOAC, 1980).

One month-old cucumber seedlings, cv. DP163, were transplanted in nine greenhouses soil naturally infested with Meloidogyne incognita. Each greenhouse was divided into 5 ridges. Seedlings were transplanted on the two sides of the ridge (40 meters in length and 1 meter in width) at a spacing of $30 \mathrm{~cm}$ between plants within the row. Surface irrigation was used. The treatments were thirteen, each applied to three rows and the last six rows were left without treatment (nematode only) to serve as control. All treatments including control received the same agricultural practices. All treatments were applied at the rate of $25 \mathrm{ml} \cdot \mathrm{m}^{-2}$, simulating application of $105 \mathrm{l.fad}^{-1}$, as soil drench added twice, after 7 and 15 days from transplanting. Plants were carefully uprooted and fresh shoot, root and fruits were weighed after 60 day from transplanting. Thereafter, the number of juveniles per $250 \mathrm{~g}$ soil and nematode populations in roots were counted according to Franklin and Goodey (1957).

The treatments under greenhouse conditions were as follows:

1- Anabaena oryzae. 2- Nostoc muscorum.

3- Oscillatoria sp.

4- Phormedium fragile.

5- Spirulina platensis.

6- Azolla pinnata aqueous extract filtrate.

7- Compost watery extract filtrate.

8- Mixture of five algae: Anabaena oryzae, Nostoc muscorum, Oscillatoria sp, Phormedium fragile and Spirulina platensis (Mix).

9- Mix + Azolla pinnata aqueous extract filtrate. 10-Mix + Compost watery extract filtrate. 11- Azolla pinnata extract + Compost watery extract filtrate.

12- Mix + Compost watery extract filtrate + Azolla pinnata aqueous extract filtrate.

13- Vydate as chemical nematicide at the recommended concentration $(24 \% \mathrm{Ec})$. 
14- Control with nematodes only (without any treatments).

Data were analyzed in the Central Laboratory for Design and Statistical Analyses in the Agricultural Research Center, Egypt. Data were subjected to statistical analyses "ANOVA" as described by Sendecor and Cochran (1980).

\subsection{Soil biological and chemical analyses}

2.6.1. Soil biological activity: $\mathrm{CO}_{2}$ evolution was determined according to Gaur et al. (1971), total bacterial count was performed on nutrient agar using the spread plate method (APHA, 1985), total cyanobacterial counts by plating ten-fold serial soil suspension-dilutions in triplicate onto agarized $\mathrm{BG}_{11}$ medium (Stanier et al., 1971). Soil enzymes, i.e., dehydrogenase activity (DHA), was estimated according to Casida et al. (1964), while nitrogenase activity was measured by acetylene reduction assay as described by Dart et al. (1972). 2.6.2. Soil chemical analyses: Soluble nitrogen forms $\left(\mathrm{NH}_{4}{ }^{+}, \mathrm{NO}_{2}^{-}\right.$and $\left.\mathrm{NO}_{3}{ }^{-} \mathrm{N}\right)$ were determined in the soil extract which was prepared according to Allam (1951). $\mathrm{NH}_{4}{ }^{+}$-N was determined by the method described by Fawcett and Scott (1960), while $\mathrm{NO}_{2}^{-}$and $\mathrm{NO}_{3}^{-}-\mathrm{N}$ were determined according to Deutsche Einheitsverfahren (1960). Available phosphorus was extracted using the method described by Soltanpour (1985) and determined spectrophotometrically as mentioned by Olsen and Watanabe, (1965). Available potassium was extracted using the method described by Soltanpour (1985) and determined using flame-photometric method (APHA, 1992). Soil reaction $(\mathrm{pH})$ was measured in 1:2.5 soil water extract using glass electrode $\mathrm{pH}$ meter Model (955), and electric conductivity (EC) was measured in 1:5 soil water extract using glass electrode conductivity meter Model Jenway 4310.

\section{RESULTS AND DISCUSSION}

3.1. Efficacy of algal culture filtrates, $A$. pinnata aqueous extract filtrate and compost watery extract filtrate on the activity of $M$. incognita juveniles under laboratory conditions

Data in Table (4) illustrate that all treatment filtrates had various degrees of effectiveness toward the mortality $\%$ of nematode juveniles. Moreover, the percentage of mortality increased with increasing the concentration and exposure period. Spirulina platensis (1:10) recorded the highest mortality percentages of nematode juveniles of 79.2, 81.3 and 84.3 after 24,48 and 72 hrs. exposure time, respectively. Oscillatoria sp, A. oryzae, N. muscorum, $P$. fragile, compost watery extract and Azolla pinnata aqueous extract ranked in the second level in nematode juveniles mortality Data \% at 1:10 during all exposure periods. These treatments showed a lethal effect on nematode juveniles and the mortality percentages were over 70 after 24 hours exposure, except compost watery extract and A. pinnata aqueous extract which achieved 66.9 and $65.4 \%$ respectively. By increasing the exposure period to 72 hrs. the mortality percentages raised to 80.4 , $78.9, \quad 75.4,72.5, \quad 70.1$ and $69.8 \%$ with Oscillatoria sp, A. oryzae, $N$. muscorum, $P$. fragile, compost watery extract filtrate and Azolla pinnata aqueous extract filtrate; respectively. On the other hand, Chlorella vulgaris had the lowest effect on nematode juveniles percentage (44.2) by the end of the exposure period (72 hrs.).

The obtained results indicated that blue green algae such as Spirulina platensis, Oscillatoria sp., Anabaena oryzae, Nostoc muscorum and Phormedium fragile produce a great variety of secondary metabolites (Gervick et al., 2001), such as nitrogen-containing compounds, polyketides, lipopeptides, cyclic peptides and many others. The efficacies of these algal culture filtrates decreased with their dilution, that may be due to the differences in toxic substances present in the culture filtrates. Similarly, Khan et al. (1997) reported that the efficacy of culture filtrates of the cyanobacterium Microcoleus vaginatus against egg hatching and mortality of Meloidogyne incognita was dependent on its concentration and period of exposure.

The high mortality percentages recorded for nematode juveniles exposed to the algal culture filtrates may be due to the presence of some phenolic compounds and mineral salts that facilitate and accelerate the rate of penetration of algal byproducts through snail's skin, hence increasing their harmful effects (Bakry et al., 1999 and Mahmoud, 2001).

The presence of high quantities of acrylic acid in Spirulina was substantiated at the end of the seventies. This substance shows anti-microbial activity, at a $2 \mathrm{mg} / \mathrm{l}$ of biomass concentration. Propionic, benzoic and mandelic organic acids were also found (Lee, 2004). Abd El-Baky et al. (2009) indicated that $S$. platensis secretes organic substances or metabolic products such as phycobiline, phenols, terpenoids, steroids, polysaccharides and saponins. Low concentrations of saponin fractions increased mortality of $B$. alexandrina snails, miracidia, cercariae and adult worms of Schistosoma mansoni, and decrease atchability and egg production (Tadros et al., 2008). 


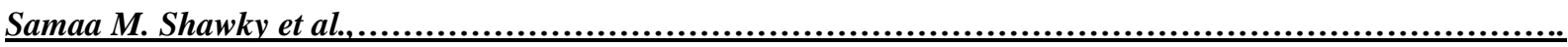

Table (4): Effect of algal culture filtrates, A. pinnata aqueous extract filtrate and compost watery extract filtrate on the activity of $M$. incognita juveniles after different exposure periods under laboratory conditions.

\begin{tabular}{|c|c|c|c|c|}
\hline & \multirow{3}{*}{ Conc. } & \multicolumn{3}{|c|}{ Exposure periods (in hours) } \\
\hline & & 24 & 48 & 72 \\
\hline & & \multicolumn{3}{|c|}{ Mortality \% } \\
\hline \multicolumn{2}{|l|}{ Control (Nematode only) } & 0.9 & 1.2 & 1.8 \\
\hline \multirow{3}{*}{ Anabaena flos aquae } & $1: 50$ & 34.7 & 38.1 & 40.4 \\
\hline & $1: 25$ & 41.5 & 43.5 & 47.5 \\
\hline & $1: 10$ & 45.4 & 50.2 & 52.1 \\
\hline \multirow{3}{*}{ Anabaena oryzae } & $1: 50$ & 60.4 & 64.5 & 67.2 \\
\hline & $1: 25$ & 68.3 & 70.2 & 73.7 \\
\hline & $1: 10$ & 73.4 & 75.6 & 78.9 \\
\hline \multirow{3}{*}{ Chlorella vulgaris } & $1: 50$ & 32.2 & 35.2 & 37.5 \\
\hline & $1: 25$ & 35.9 & 38.8 & 40.1 \\
\hline & $1: 10$ & 40.1 & 42.4 & 44.2 \\
\hline \multirow{3}{*}{ Nostoc humifusum } & $1: 50$ & 50.4 & 53.2 & 57.6 \\
\hline & $1: 25$ & $\mathbf{5 7 . 8}$ & 60.4 & 64.7 \\
\hline & $1: 10$ & 63.4 & 65.5 & 67.8 \\
\hline \multirow{3}{*}{ Nostoc muscorum } & $1: 50$ & 58.7 & 60.7 & 64.5 \\
\hline & $1: 25$ & 66.8 & 68.1 & 71.9 \\
\hline & $1: 10$ & 70.6 & 72.9 & 75.4 \\
\hline \multirow{3}{*}{ Oscillatoria sp. } & $1: 50$ & 66.4 & 68.2 & 70.2 \\
\hline & $1: 25$ & 71.3 & 74.1 & 76.9 \\
\hline & $1: 10$ & 76.9 & 78.2 & 80.4 \\
\hline \multirow{3}{*}{ Phormedium fragile } & $1: 50$ & 55.6 & 58.4 & 62.1 \\
\hline & $1: 25$ & 64.8 & 67.5 & 70.4 \\
\hline & $1: 10$ & 68.1 & 70.7 & 72.5 \\
\hline \multirow{3}{*}{ Spirulina platensis } & $1: 50$ & 70.2 & 74.8 & 79.1 \\
\hline & $1: 25$ & 75.8 & 78.3 & 82.5 \\
\hline & $1: 10$ & 79.2 & 81.3 & 84.3 \\
\hline \multirow{3}{*}{ Wollea saccata } & $1: 50$ & 49.5 & 50.5 & 54.9 \\
\hline & $1: 25$ & 55.6 & 57.4 & 60.7 \\
\hline & $1: 10$ & 61.3 & 64.7 & 65.1 \\
\hline \multirow{3}{*}{$\begin{array}{l}\text { Azolla pinnata (aqueous } \\
\text { extract filtrate) }\end{array}$} & $1: 50$ & 51.8 & 54.4 & 58.9 \\
\hline & $1: 25$ & 60.9 & 63.7 & 65.4 \\
\hline & $1: 10$ & 65.4 & 67.3 & 69.8 \\
\hline \multirow{3}{*}{ Compost extract } & $1: 50$ & 53.8 & 56.1 & 60.7 \\
\hline & $1: 25$ & 62.7 & 66.8 & 68.5 \\
\hline & $1: 10$ & 66.9 & 68.4 & 70.1 \\
\hline \multicolumn{2}{|c|}{ Vydate (recommended concentration) } & 84.5 & 87.4 & 90.7 \\
\hline
\end{tabular}


3.2. Efficacy of algal culture filtrates, $A$. pinnata aqueous extract filtrate and compost watery extract filtrate in combination or single application on cucumber infection by $M$. incognita under greenhouse conditions

All tested algal culture filtrates, A. pinnata aqueous extract filtrate and compost watery extract filtrate in single and/or in combined applications caused a remarkable decrease in the number of root galls under greenhouse conditions. Fig. (1) shows that the combination treatment of Mix (five algae of $A$. oryzae, $N$. muscorum, Oscillatoria sp. P. fragile and S. platensis) with A. pinnata aqueous extract filtrate and compost watery extract filtrate resulted in the lowest number of root galls, whereas, the individual treatment of $A$. pinnata showed the highest number of root galls compared to the other treatments. The same trend was obtained with number of developmental stages, females, egg masses and eggs numbers/root. Data in Table (5) reveal that the combination of Mix (five algae of A. oryzae, N. muscorum, Oscillatoria sp. P. fragile and $S$. platensis) with $A$. pinnata extract and compost extract resulted in the lowest final population numbers of $M$. incognita (PF) compared with the other treatments, whereas the highest final population of $M$. incognita was associated with the individual treatment of $A$. pinnata only after two months from treatment application. The present results indicate that the combination of the algal culture filtrates, compost extract and A. pinnata extract induced resistance in cucumber roots against $M$. incognita. The same results were achieved by Khan et al. (2005), who suggested that the application of algal filtrate might have helped the plant to resist nematode attack or may have played a direct role in the plant defense mechanism. Microorganisms and compounds of microbial origin have been found to induce defense responses and/or resistance in plants towards pathogens.

Fig. (2) illustrates that the combination treatment of Mix (five algae) with A. pinnata and compost caused the highest reduction in \% of $M$. incognita (which reached 85.3) ,compared to the other treatments, while the individual treatment of A. pinnata showed the lowest reduction $\%$ of M.incognita, being 56.8 after two months from treatments.

Fig. (3) shows shoots and roots fresh weights of the cucumber plants infected with nematode. The results are expressed as percentage of increase over the control. The data indicated that the increase $\%$ of fresh weight of the whole plant was greatly improved with the combination treatment of the five algal culture filtrates with $A$.

pinnata and compost water extract filtrates where the percentage of increase reached $84.5 \%$,. The individual treatment of $A$. pinnata recorded the lowest value in the percentage of increase of fresh weight of the whole plant $(50.4 \%)$.

Yield of cucumber plants infected with nematode in the greenhouse is shown in Fig. (4). The data indicate that the yield was the highest with the combined treatment of mix of algal culture filtrates with $A$. pinnata and compost water extracts (3400 g plant $\left.{ }^{-1}\right)$, while, the individual treatment of $A$. pinnata aqueous extract recorded the lowest value of $2300 \mathrm{~g} \mathrm{plant}^{-1}$. Liu et al. (2008) found that the stimulation of plant growth by using compost + compost tea or seaweed extracts may be attributed to the combined effect of compost, compost tea (which contains humic acids, vitamins, amino acids and both macro and micro nutrients which enhanced cucumber growth) and seaweed extracts which contain some growth regulators such as cytokinins, auxin and gibberellins. Actively aerated compost extract, which is supplied with active aeration of high oxygen concentration, stimulates population growth of aerobic microbes, which helps disease prevention, nutrient cycling, retention of micronutrients, soil structure, and decomposition of plant-toxic materials. Moreover compost extract mode of action could be attributed to release of compounds toxic to nematodes, like ammonia $\left(\mathrm{NH}_{3}\right)$, nitrites, hydrogen sulphide, polyphenols and tannins (Rivera and Aballay, 2007). Soil organic amendments have been used as an alternative dual method in the control of nematodes and improving plant growth and its yield (Hasabo, 2006). Organic matter affects nematode populations in two different ways, directly by possessing nematicidal properties during its degradation (Sitaramaiah and Singh, 1978), or indirectly by enhancing the development of nematode natural enemies (Hasabo, 2006). Also, Rotenberg et al. (2005) reported that additions of organic amendments (composts) to agricultural soils can lead to improved soil quality and reduced severity of crop diseases as well as increased cucumber yield.

Khan et al. (2005) studied the nematicidal potential of culture filtrates of the blue-green alga, Microcoleus vaginatus (Cyanobacterium). against Meloidogyne incognita on tomato under greenhouse conditions. Prior to the transplantation 


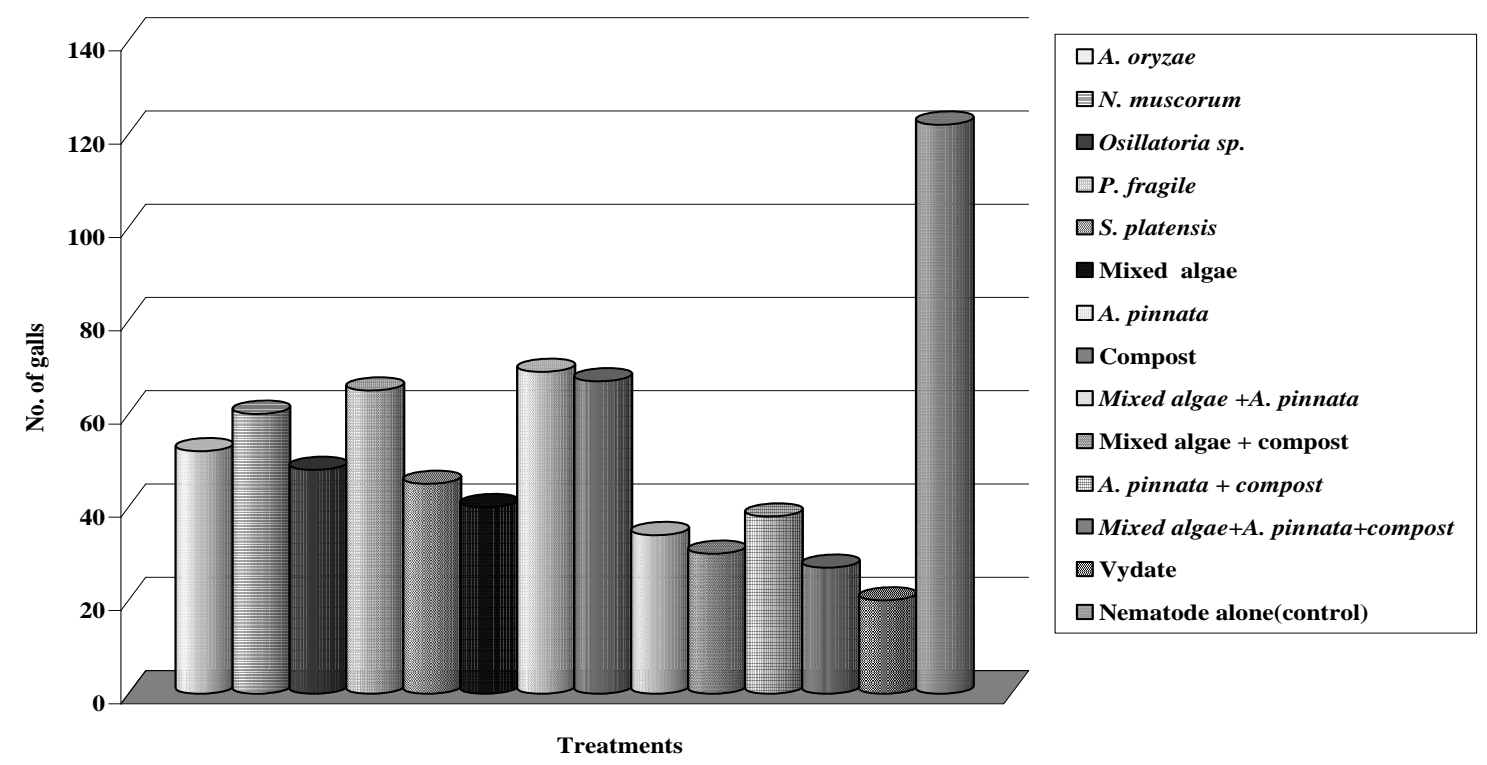

Fig (1): Effect of algal culture filtrates, A. pinnata aqueous extract filtrate and compost watery extract filtrate, individually and/or in combination on the number of galls of $M$. incognita on cucumber plants.

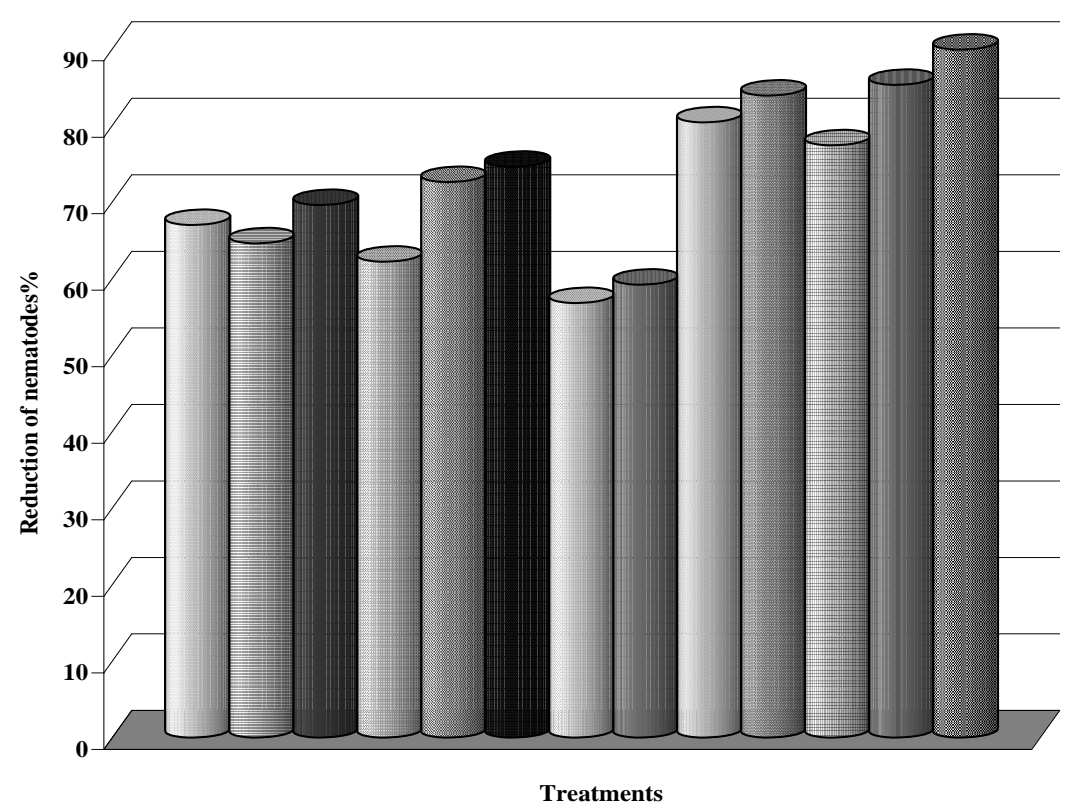

\begin{tabular}{|l|}
\hline A. oryzae \\
$\square$ N. muscorum \\
$\square$ Osillatoria sp. \\
$\square$ P. fragile \\
$\square$ S. platensis \\
$\square$ Mixed algae \\
$\square$ A. pinnata \\
$\square$ Compost \\
$\square$ Mixed algae +A. pinnata \\
$\square$ Mixed algae + compost \\
$\square$ A. pinnata + compost \\
$\square$ Mixed algae+A. pinnata+compost \\
$\square$ Vydate
\end{tabular}

Fig. (2): Effect of a algal culture filtrates, A. pinnata aqueous extract filtrate and compost extract individually and/or in combined application on the reduction of nematodes\% on cucumber plants. 
Table (5): Efficacy of algal culture filtrates, A. pinnata aqueous extract filtrate and compost extract, individully and/or in combined Application, on the reproduction of $M$. incognita infecting cucumber plants under greenhouse conditions.

\begin{tabular}{|c|c|c|c|c|c|c|}
\hline \multirow[b]{2}{*}{ Treatments } & \multicolumn{6}{|c|}{ Nematode population } \\
\hline & $\begin{array}{c}\text { No. of } \\
\text { juveniles in } \\
\text { soil/250g } \\
\end{array}$ & $\begin{array}{c}\text { No. of } \\
\text { developmental } \\
\text { stages/root } \\
\end{array}$ & $\begin{array}{c}\text { No. of } \\
\text { females/ } \\
\text { root }\end{array}$ & $\begin{array}{c}\text { No. of egg- } \\
\text { masses/ } \\
\text { root }\end{array}$ & $\begin{array}{l}\text { No. of eggs/ } \\
\text { egg-mass/root }\end{array}$ & $\begin{array}{c}\text { Final nematode } \\
\text { population } \\
(\mathrm{PF})\end{array}$ \\
\hline Control with nematode & 2200 & 108 & 122 & 118 & 410 & 50810 \\
\hline Anabaena oryza & 420 & 62 & 52 & 48 & 338 & 16758 \\
\hline Nostoc muscorum & 480 & 65 & 60 & 51 & 340 & 17945 \\
\hline Oscillatoria $\mathrm{sp}$. & 380 & 58 & 48 & 45 & 332 & 15426 \\
\hline Phormidium fragile & 540 & 67 & 65 & 54 & 343 & 19194 \\
\hline Spirulina platensis & 340 & 55 & 45 & 41 & 328 & 13888 \\
\hline Mixed algae & 300 & 52 & 40 & 39 & 320 & 12872 \\
\hline Azolla pinnata & 660 & 73 & 69 & 60 & 352 & 21922 \\
\hline Compost & 600 & 71 & 67 & 57 & 350 & 20688 \\
\hline Mixed algae $+A$. pinnata & 320 & 48 & 34 & 31 & 308 & 9950 \\
\hline Mixed algae+Compost & 220 & 45 & 30 & 27 & 291 & 8152 \\
\hline A. pinnata + Compost & 260 & 50 & 38 & 35 & 317 & 11443 \\
\hline $\begin{array}{l}\text { Mixed algae }+A . \\
\text { pinnata+Compost }\end{array}$ & 180 & 43 & 27 & 25 & 288 & 7450 \\
\hline Vydate & 100 & 28 & 20 & 19 & 260 & 5088 \\
\hline L.S.D. $(5 \%)$ & 43 & 3 & 3 & 2 & 2.6 & 113 \\
\hline
\end{tabular}


Table (6): The biological activity of $M$. incognita infected soil remaining after cucumber harvesting.

\begin{tabular}{|c|c|c|c|c|c|}
\hline Treatments & 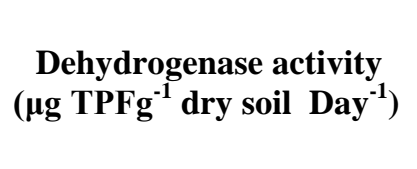 & $\begin{array}{l}\text { Nitrogenase activity } \\
\qquad\left(\mu \text { mole } \mathrm{C}_{2} \mathbf{H}_{4}\right. \\
\left.\text { g soil }^{-1} \mathrm{hr}^{-1}\right)\end{array}$ & $\begin{array}{c}\mathrm{CO}_{2} \\
\text { evolution } \\
\left(\begin{array}{c}\mathrm{mg100g}^{-1} \text { soil }^{-1} \\
\left.\text { day }^{-1}\right)\end{array}\right.\end{array}$ & $\begin{array}{l}\text { Total bacterial } \\
\text { count }\left(\mathbf{1 0}^{5} \mathrm{cfu}\right. \\
\left.\text { g soil }{ }^{-1}\right)\end{array}$ & $\begin{array}{l}\text { Total cyano- } \\
\text { bacterial } \\
\text { count }\left(1^{2} \text { cfu }\right. \\
\left.\text { g soil }^{-1}\right)\end{array}$ \\
\hline Control with nematode & 19.53 & 13.95 & 5.41 & 37 & 2.0 \\
\hline Anabaena oryzae & 29.23 & 25.51 & 10.82 & 114 & 5.6 \\
\hline Nostoc muscorum & 34.84 & 122.59 & 12.27 & 140 & 10.0 \\
\hline Oscillatoria sp. & 30.10 & 131.35 & 11.13 & 204 & 13.4 \\
\hline Phormidium fragile & 23.00 & 123.66 & 13.08 & 179 & 10.7 \\
\hline Spirulina platensis & 30.24 & 149.65 & 13.24 & 210 & 15.8 \\
\hline Mixed-algae & 35.83 & 175.50 & 16.08 & 270 & 18.4 \\
\hline Azolla pinnata & 27.13 & 127.36 & 14.21 & 192 & 11.8 \\
\hline Compost & 35.38 & 156.54 & 15.55 & 220 & 16.1 \\
\hline Mix + Azolla pinnata & 37.66 & 258.86 & 18.81 & 388 & 22.2 \\
\hline Mix+Compost & 57.46 & 262.69 & 19.28 & 516 & 30.0 \\
\hline A. pinnata + Compost & 39.16 & 243.12 & 17.45 & 310 & 21.0 \\
\hline Mix + A. pinnata + Compost & 58.75 & 291.33 & 19.73 & 720 & 33.5 \\
\hline Vydate & 60.13 & 294.21 & 20.25 & 810 & 35.0 \\
\hline L.S.D. $(5 \%)$ & 0.44 & 1.12 & 0.46 & 5.32 & 0.26 \\
\hline
\end{tabular}




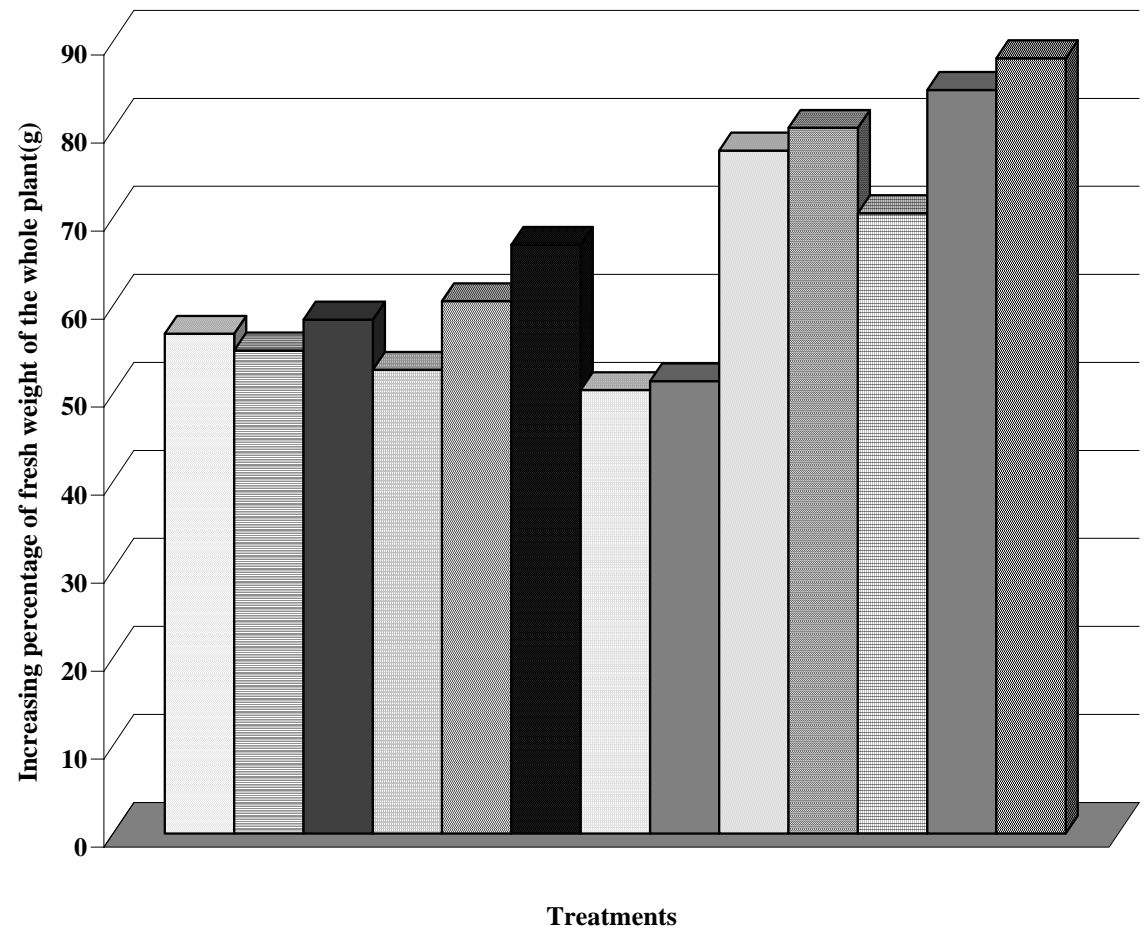

$\square$ A. oryzae

目N. muscorum

口Osillatoria sp.

$\square$ P. fragile

$\square$ S. platensis

Q Mixed algae

$\square$ A. pinnata

$\square$ Compost

$\square$ Mixed algae + A. pinnata

$\square$ Mixed algae + compost

曰A. pinnata + compost

$\square$ Mixed algae $+A$. pinnata+compost

$\square$ Vydate

Fig. (3): Effect of algal culture filtrates, A. pinnata aqueous extract filtrate and compost extract, individually and/or in combined application on the fresh weight of shoots and roots increasing \% over the control of cucumber infected by $M$. incognita.

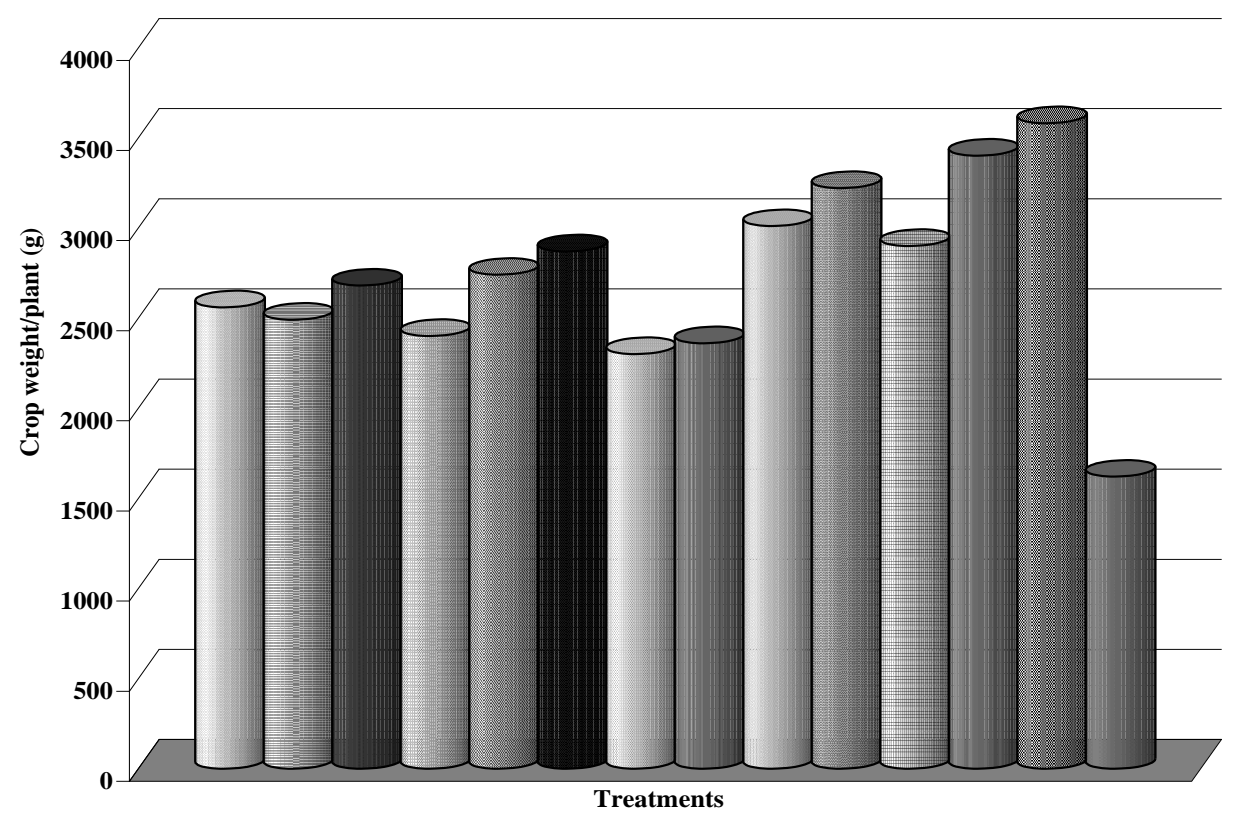

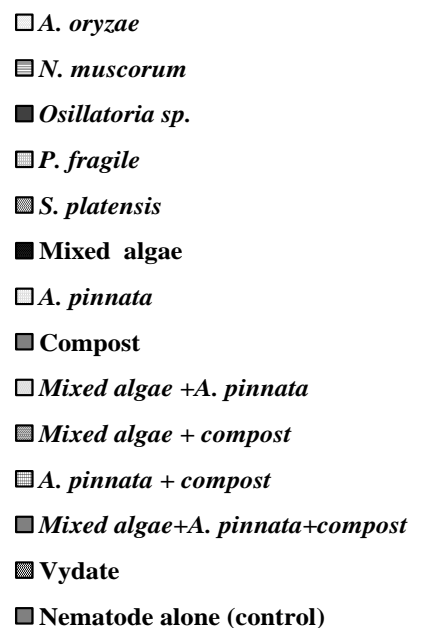

Fig. (4): Effect of algal culture filtrates, A. pinnata aqueous extract filtrate and compost extract, individually and/or in combined application on the yield of cucumber plants infected by M. incognita . 
of tomato seedlings, roots were dipped in different concentrations $(0.2,0.5,1,2,10,50$ and $100 \%)$ of culture filtrate of M.vaginatus for $30 \mathrm{~min}$. Root dip treatment reduced the root galling and final population of $M$. incognita and increased vegetative growth of plants and root-mass production compared to the control. The beneficial effect of root-dip treatment increased with increasing culture filtrate concentration. Root galling and final nematode populations were reduced by 65.9 and $97.5 \%$, respectively, when treated at the highest concentration. On the other hand, three species of blue green algae, Anabena oryzae, Nostoc calcicola and Spirulina sp., were tested versus Meloidogyne incognita infecting cowpea cv. Baladi in single and/or in combined treatments. It was found that $N$. calcicola alga was superior to all the other treatments followed by Spirulina sp., in reducing the number of nematode galls and egg masses as compared to the untreated treatment. In combined treatments, the 3 algae together achieved the highest significant reduction in the number of galls and egg masses. All the treatments significantly improved plant growth criteria as measured by fresh and dry weight of shoots and roots and length of shoots and increased the number of nodules (Youssef and Ali, 1998).

3.3. The biological and chemical analyses of $M$. incognita infected soil remaining after cucumber harvesting. The remaining soil after cucumber harvesting was analyzed to spot the changes in soil biological and chemical conditions due to the different treatments in the greenhouse experiment. Generally, all the combined treatments enhanced soil biological activity than the individual ones (Table 6).

However, the superiority of biological activity of the soil was due to the synthetic nematicide (Vydate). The combined treatment of mixed algal culture filtrates $+A$. pinnata aqueous extract filtrate + compost extract revealed the highest soil biological activity compared with other remain treatments and achieved values of dehydrogenase $\left(58.75 \mu \mathrm{g}\right.$ TPF $\mathrm{g}^{-1}$ dry soil day $\left.^{-1}\right)$, nitrogenase (291.33 $\mu$ mole $\mathrm{C}_{2} \mathrm{H}_{4} \mathrm{~g}$ dry soil $\left.^{-1} \mathrm{hr}^{-1}\right), \mathrm{CO}_{2}$ evolution $\left(19.73 \mathrm{mg} 100 \mathrm{~g}\right.$ soil $^{-1}$ day $\left.^{-1}\right)$, total bacterial count $\left(720 \times 10^{5} \mathrm{~g} \mathrm{cfu}^{\mathrm{g}}\right.$ soil $\left.^{-1}\right)$ and cyano- bacterial count $\left(33.5 \times 10^{2} \mathrm{cfu} \mathrm{g}^{\mathrm{g}}\right.$ soil $\left.^{-1}\right)$. These results are in agreement with those obtained by Mahmoud et al. (2007), who reported that cyanobacteria combined with organic amendments significantly enhanced the soil biological activity in terms of increasing the total bacterial, total dehydrogenase, nitrogenase and phosphatase activities. The data in Table (7) show the chemical properties of the soil after cucumber harvest. The results indicate that the combined treatment of mix of algal culture filtrates, $A$. pinnata aqueous extract filtrate and compost extract increased significantly the soil available nitrogen forms $\left(\mathrm{NH}_{4}{ }^{+}, \mathrm{NO}_{3}^{--}\right.$and $\left.\mathrm{NO}_{2}^{--}\right)$, as well as $\mathrm{K}$ and $\mathrm{P}$ over the control. The corresponding $\mathrm{K}$ and $\mathrm{P}$ values were 80.33 and $17.76 \mathrm{ppm}$. The soluble nitrogen forms were investigated in all treatments. The highest values were 10.0, 76.12 and $0.51 \mathrm{ppm}$ in the treatment of the combination between mix of algal culture filtrates, A. pinnata aqueous extract filtrate and compost extract for ammoniac, nitrate and nitrite-nitrogen, respectively.

Generally, the combined treatments revealed higher ammoniacal levels in the soil than the remaining treatments. The high rates of $\mathrm{N}$ required for consistent nematicidal activity from ammoniacal fertilizers can be expected to result in significant phytotoxicity through the accumulation of metabolic byproducts in the soil (RodriguezKabana, 1986). These results agree with Omar and Shawky (2006) who stated that the increase of ammonium levels around tomato rhizosphere caused a high reduction of nematode population.

The action of soil microorganisms on an organic material during the decomposition process can produce a wide range of chemicals like ammonia, nitrites, hydrogen sulfide, organic acids and enzymes (Stirling, 1991). These chemicals are known to possess nematicidal properties that affect egg hatch and/or motility of juveniles (Korayem, 2003).

The effectiveness of organic amendments to control nematodes is a function of the $\mathrm{C}: \mathrm{N}$ ratio and time of microbial decomposition of organic matter and subsequent release of nitrogen for utilization by higher plants. With organic matter of a C:N ratio greater than 20:1, $\mathrm{N}$ will temporarily be immobilized in microbial tissue, creating a nitrogen deficiency. The nematode management potential of an organic soil amendment is directly related to $\mathrm{N}$-content or inversely related to the $\mathrm{C}: \mathrm{N}$ ratio. Amendments with narrow $\mathrm{C}: \mathrm{N}$ ratios result in better nematode control than those with wide ratios (Agbenin, 2004). However, it is possible that nematicidal activity of nitrogenous by-products should be most evident when $\mathrm{C}: \mathrm{N}$ ratio of the compost is less than 20: 1 (Stirling, 1991). The $\mathrm{pH}$ of the soil (Table 7) was affected by the organic and biological treatments. However, its nematicide 
Table (7): Some chemical properties of $M$. incognita infected soil remaining after cucumber harvesting.

\begin{tabular}{|c|c|c|c|c|c|c|c|}
\hline \multirow{2}{*}{ Treatments } & \multirow{2}{*}{$\begin{array}{c}\text { Available - } \\
\text { K (ppm) }\end{array}$} & \multirow{2}{*}{$\begin{array}{c}\text { Available - } \\
\text { P (ppm) }\end{array}$} & \multicolumn{3}{|c|}{ Available-N } & \multirow{2}{*}{$\mathbf{p H}$} & \multirow{2}{*}{ Ec } \\
\hline & & & $\mathrm{NH}_{4}{ }^{+}$ & $\mathrm{NO}_{3}{ }^{--}$ & $\mathrm{NO}_{2}^{--}$ & & \\
\hline Control with nematode & 22.11 & 9.46 & 2.45 & 31.82 & 0.04 & 8.57 & 0.76 \\
\hline Anabaena oryzae & 51.50 & 11.04 & 3.02 & 60.23 & 0.54 & 7.77 & 0.54 \\
\hline Nostoc muscorum & 47.05 & 11.44 & 0.82 & 71.59 & 0.57 & 8.00 & 0.55 \\
\hline Oscillatoria $S p$. & 51.34 & 12.27 & 2.80 & 44.25 & 0.61 & 8.09 & 0.48 \\
\hline Phormidium fragile & 65.37 & 12.95 & 2.16 & 45.45 & 0.57 & 7.50 & 0.55 \\
\hline Spirulina platensis & 54.09 & 13.79 & 1.32 & 52.27 & 0.94 & 8.17 & 0.67 \\
\hline Mixed-algae & 61.75 & 16.44 & 3.50 & 72.18 & 0.57 & 8.10 & 0.49 \\
\hline Azolla pinnata & 57.25 & 11.89 & 3.30 & 73.18 & 0.81 & 7.95 & $\mathbf{0 . 5 3}$ \\
\hline Compost & 66.37 & 14.80 & 2.80 & 69.32 & 0.54 & 8.10 & 0.46 \\
\hline $\mathrm{Mix}+$ A. pinnata & 76.95 & 15.35 & 7.05 & 79.55 & 0.41 & 8.00 & 0.48 \\
\hline Mix+Compost & 77.45 & 16.57 & 5.93 & 75.00 & 0.54 & 8.30 & 0.47 \\
\hline A. pinnata + Compost & 75.04 & 15.05 & 4.25 & 73.52 & 1.01 & 8.20 & 0.47 \\
\hline Mix + A. pinnata + Compost & 80.33 & 17.76 & 10.00 & 76.12 & 0.51 & 8.25 & 0.45 \\
\hline Vydate & 85.40 & 18.22 & 11.18 & 77.27 & 0.61 & 8.62 & 0.45 \\
\hline L.S.D. $(5 \%)$ & 0.21 & 0.19 & 0.14 & 1.27 & 0.05 & 0.01 & 0.02 \\
\hline
\end{tabular}


cyanobacterial counts, $\mathrm{CO}_{2}$ evolution, effects would be due mainly to the release of ammonia in a slightly alkaline $\mathrm{pH}$ and a $\mathrm{C} / \mathrm{N}$ proportion within the optimal range, according to Stirling (1991). The combined treatments led to a slight reduction in soil electrical conductivity (Table, 7). Biological inoculation of soil led to a reduction in soil $\mathrm{pH}$ and electrical conductivity (El-Gaml, 2006).

\section{REFERENCES}

Abad P., Favery B., Rosso M. and CastagnoneSereno P. (2003). Root-knot nematode parasitism and host response: molecular basis of a sophisticated interaction. Mol. Pl. Path., 4 : 217-224.

Abd El-Baky H.H., El Baz F.K. and El-Baroty G.S. (2009). Phenolics from Spirulina maxima: Over-production and in vitro protective effect of its phenolics on $\mathrm{CCl} 4$ induced hepatotoxicity. Journal of Medicinal Plants Research, 3(1): 24-30.

Agbenin O.N. (2004). Potentials of organic amendments in the control of plant parasitic nematodes. Plant Protect. Sci., 40(1): 2125.

Al-Dahmani J.H., Abbasi P.A., Miller S.A. and Hoitink H.A.J. (2003). Suppression of bacterial spot of tomato with foliar sprays of compost extracts under greenhouse and field conditions. Plant Disease, 87(8): 913919.

Allam F. (1951). The Keening Method for the Determination of Available Soil Nitrogen. Analytical Agric. Chem., Part. 1, Cairo (Arabic Text).

Anastasiadis I.A., Giannakou I.O., ProphetouAthanasiadou D.A. and Gowen S.R. (2008). The combined effect of the application of a biocontrol agent Paecilomyces lilacinus, with various practices for the control of root-knot nematodes. Crop Prot., 27: 352361.

AOAC (1980). Official Methods of Analysis of the Association of Official Analytical Chemist. $12^{\text {th }}$ ed. Washington, D.C., USA.

APHA American Public Health Association (1985). Standard Methods for Water and Wastewater Analyses, $13^{\text {th }}$ ed., Washington D.C., USA.

APHA American Public Health Association (1992). Standard Methods Examination of Wastewater, $17^{\text {th }}$ ed. American Public
Health Association, Washington D.C., p. 116.

Bakry F., El-Dafrawy S., El-Sayed K., Sharaf ElDin A. and Gawish F. (1999). Effect of certain salts on susceptibility of Biomphalaria alexandrina snails to Schistosoma mansoni and Echinostoma liei Infection. J. Union. Arab. Biol., 11 (A) Zool.: 193-204.

Bayoumi Y.A. and Hafez Y. M. (2006). Effect of organic fertilizers combined with benzo (1, 2,3) thiadiazole-7-carbothioic acid S-methyl ester (BTH) on the cucumber powdery mildew and the yield production. Acta Biologica Szegediensis, 50(3-4): 131-136.

Casida L. E., Klein D.A. and Santoro T. (1964). Soil dehydrogenase activity. Soil Sci., 98: 371-376.

Dart P.J., Day J.M. and Harris D. (1972). Assay of nitrogenase activity by acetylene reduction. In: Use of isotopes for study of fertilizer utilization by legume crops. FAO/IAEA Technical Report Series, 149: 85-97.

Deutsche Einheitsverfahren (1960). Gesellschaft Dentscher Chemiker Fachgruppe Wasser Chem. "Deutsche Einheitsverfahren zur Wasser, Abwasser und Schlamm. Untersuchung" VerlagChemie, Gmbh, $\mathrm{D}_{9}$, $\mathrm{D}_{10}$. Weinhein, Bergstr, W. Germany.

Dhanam M., Kumar A.C. and Sowajanya A.S. (1994). Microcoleu vaginatus (Oscillatoriaceae), a blue-green alga (Cyanobacterium) parasitizing plant and soil nematodes. Indian Journal of Nematology, 24: 125-132.

El Gaml N.M.M. (2006). Studies on Cyanobacteria and Their Effect on Some Soil properties. M. Sc. Thesis, Soil Dept., Faculty of Agriculture, Benha University, Kalubia Governorate, Egypt.

El-Gendy R.S.S. and Shawky, S.M.S. (2006). Efficacy of some natural plants and bioagents to minimize the population of root-knot nematode; Melidogyne incognita in Superior seedless vineyards and its reflection on vine growth and yield. The First Egyptian Conference of Biotechnology (264-280).

Fawcett J.K. and Scott J.F. (1960). A rapid and precise method for determination of urea. $\mathrm{J}$. Chin. Path. 13: 156-159.

Fay P. (1983). The Blue-Greens. Edward Arnold, London.

Franklin M.T. and Goodey J.B. (1957). A cottonblue lactophenol technique for mounting 
plant parasitic nemato des. J. Helminthological Abstracts, 23: 175- 178.

Gaur A.C., Sadasivan K.V., Vimal O.P. and Mathur R.S. (1971). A study of decomposition of organic matter in an alluvial soil. $\mathrm{CO}_{2}$ evolution, microbiological and chemical transformation. Plant and Soil, 34 :17-28.

Gervick W.H., Tan L.T. and Siachitta N. ( 2001). In: Cordell, G. (Ed.), The Alkaloids, Vol. 57. Academic Press, San Diego, p. 75-184.

Hasabo S.A. (2006). Management of the rootlesion nematode, Pratylenchus zeae on sugar cane by some organic and nonorganic soil amendments. Minufiya J. Agric. Res., 31: 207-219.

Khan Z., Jairajpuri M.S. and Khan M.W. (1997). Effect of culture filtrate of a blue-green alga Microcoleus vaginatus on mortality and hatching of root-knot nematode Meloidogyne incognita. International Journal of Nematology, 7: 100-102.

Khan Z., Park S.D., Shin S.Y., Bae S.G., Yeon I.K. and Seo Y.J. (2005). Management of Meloidogyne incognita on tomato by rootdip treatment in culture filtrate of the bluegreen alga Microcoleus vaginatus. Bioresource Technology, 96: 1338-1341.

Korayem A.M. (2003). Effect of some organic wastes on Meloidogyne incognita development and tomato tolerance to the nematode. Egypt. J. Phytopathol., 31:119127.

Lee Y. (2004). Microalgal mass culture system and methods: their limitation and potential. J. Appl. Phycology,13(4): 1573-5176.

Liu T., Wang L., Duan Y.X. and Wang X. (2008). Nematicidal activity of culture filtrate of Beauveria bassiana against Meloidogyne hapla. World J. Microbiol. Biotechnol., 24: 113-118.

Mahmoud A.A., Mostafa, S.S.M., Abd El-All,A. A.M. and Hegazi A.Z. (2007). Effect of cyanobacterial inoculation in presence of organic and inorganic amendments on carrot yield and sandy soil properties under drip irrigation regime. Egypt. J. of Appl. Sci., 22(12B):716-733.

Mahmoud M. B. (2001). Physiological Studies on Biomphalaria alexandrina Snails and Their Susceptibility to Schistosoma mansoni Infection. Ph.D. Thesis, Fac. Science, Ain Shams Univ., Cairo, Egypt.

Meadows J., Gill S.S. and Bone L.W. (1989). Factors influencing lethality of Bacillus thuringiensis kurstaki toxin for eggs and larvae of Trichostrongylus colubriformus (Nematoda). Journal of Parasitology, 75:191-194.

Nichols H.W. and Bold H. C. (1965). Trichosarcina polymorpha gen. et sp. nov. J. Phycol., 1:34-38.

Oka Y., Koltai H., Bar-Eyal M., Mor M., Sharon E., Chet I. and Spiegel Y. (2000). New strategies for the control of plant parasitic nematodes. Pest Manage. Sci., 56:983-988.

Olsen S. R. and Watanabe F. S. (1965). Test of an Ascorbic acid method for determining phosphorus in water and $\mathrm{Na} \mathrm{HCO}_{3}$ extract from soil. Soil Sci. Am. Proc., 29, 661.

Omar M.N.A. and Shawky, S. M. (2006). Use of nitrifications and bacterial inoculation in controlling root knot nematode Meloidogyne incognita in tomato plants. $1^{\text {st }}$ International Egyptian-Jordanian Conference on Biotechnology and Sustainable Development: Current Status and Future Scenarios. National Research Center, Cairo, Egypt.

Oostendrop M. and Sikora R. A. (1989). Seed treatment with antagonistic rhizobacteria for the suppression of Heterodera schachtii early root infection of sugar-beet. Revue Nematologie, 12:77-83.

Rippka R., Deruelles J., Waterburg J. B., Herdman M. and Stanier R.Y. (1979). Generic assignments,strain histories and properties of pure cultures of cyanobacteira. J. of General Microbiol., 111: 1-16.

Rivera L. and Aballay E. (2007). Nematicide effect of various organic soil amendments on Meloidogyne ethiopica whitehead on potted vine plants. Chilean Journal Of Agricultural Research, 68(3):290-296.

Rodriguez-Kabana R. (1986). Organic and inorganic nitrogen amendments to soil as nematode suppressants. J. of Nematology, 18:129-135.

Rotenberg D., Cooperband L., and Stone A. (2005). Dynamic relationships between soil properties and foliar disease as affected by annual additions of organic amendment to a sandy-soil vegetable production system. Soil Biol. Biochem., 37(7):1343-1357.

Sendecor G.W. and Cochran W.G. (1980). Statistical Methods. Oxford \& J.BH Publishing Co, $7^{\text {th }}$ Edition.

Shimizu Y.(2003). Microalgal metabolites. Current Opinion in Microbiology, 6:236242. 
Sitaramaiah R. and Singh R.S. (1978). Effect of organic amendments on phenolic content of soil and plant response of Meloidogyne javanica and its host to related compounds. Plant and Soil, 5: 671- 679.

Soltanpour P.N. (1985). Use of ammonium bicarbonate DTPA soil test to evaluate elemental availability and toxicity. Commun. Soil Sci. Plant Anal., 16 (3): 323338.

Stanier R.Y., Kunisawa R., Mandel M. and Cohen-Bazire G. (1971). Purification and properties of unicellular blue-green algae (Order Chroococcales), Bacteriol. Rev., 3: 1711-20.5.

Stirling C.R. (1991). Biological Control of Plant Parasitic Nematodes. Progress, Problems and Prospects. CAB International, Wallingford, Oxon, UK,. $282 \mathrm{pp}$.

Tadros M.M., Ghaly N.S. and Moharib M.N. (2008). Molluscicidal and schistosomicidal activities of a steroidal saponins-containing fraction from Dracaena fragrans (L.). J. Egypt. Soc. Parasitol., 38 (2) : 585-598.
Westcott III S.W. and Kluepfel D.A. (1993). Inhibition of Criconemella xenoplax egg hatch by Pseudomonas aureofaciens. Phytopathology, 83: 1245-1249.

Yoshida S., Forno D.A., Cock J.H. and Gomez K.A. (1976). Laboratory Manual for Physiological Studies for Rice. I.R.R.I., The Philippines.

Youssef M.M.A. and Ali M.S. (1998). Management of Meloidogyne incognita infecting cowpea by using some native blue green algae. Anzeiger für Schädlingskunde, 71(1): 15-16.

Zaccaro M.C., Salazar C., Zulpa de G., Caire Stroni de M.M., Cans and Stella A.M. (2001). Lead toxicity in cyanobacterial prophyrin metabolism. Environ. Toxocol.and water Quality, 16: 61-67.

Zarrouk C. (1966). Contribution á l'étude d'une cyanophycée. Influence de divers facteurs physiques et chimiques sur la croissance et la photosynthése de Spirulina maxima (Setch. Et Gardner) Geitler. Ph. D. Thesis, University of Paris, France. 


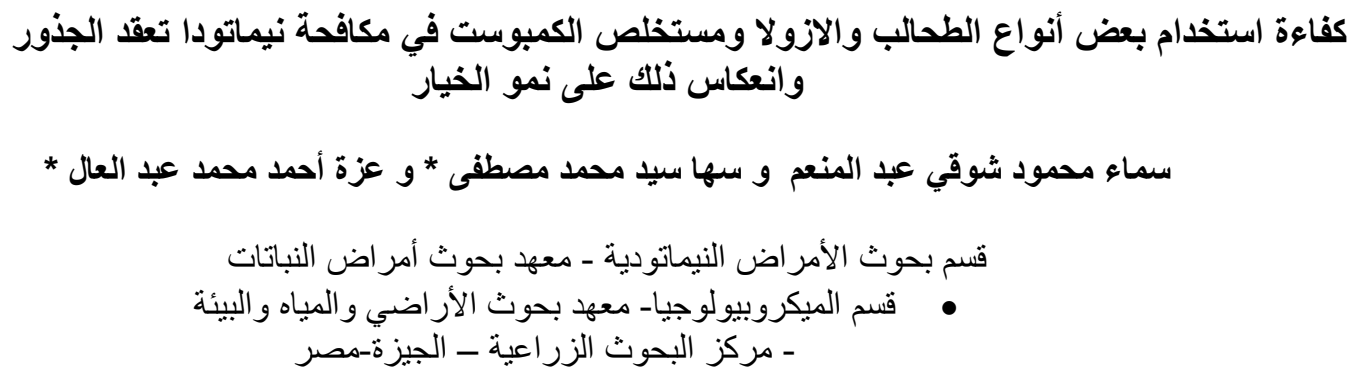

تهدف هذه الدر اسة إلى إستخدام راشح تسع مزارع سلالات طحلبية وهي: Anabaena flos aquae ، Anabaena oryzae ،

، Spirulina platensis ، Nostoc humifusum ، Nostoc muscorum ،Chlorella vulgaris ،Oscillatoria sp. Wollea saccata بPhormedium fragile بالإضافة إلى راشح المستخلص المائي لنبات Azolla pinnata (50:1) و المستخلص المائي للكمبوست (5:1) لمقاومة نيماتودا تعقد الجذور Meloidogyne incognita و التي تصيب الخيار تحت ظروف كلا من المعمل و الصوبة.

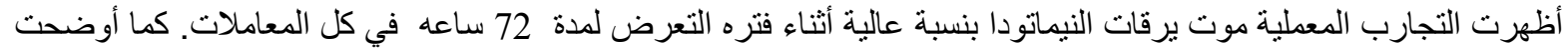

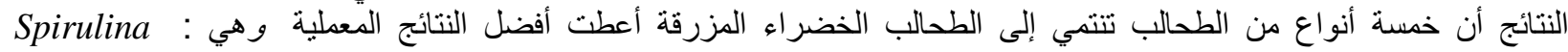
Nostoc muscorum ، Anabaena oryzae، Oscillatoria sp. ، platensis

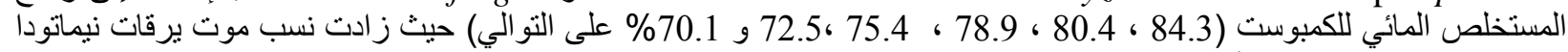
تعقد الجذور عن 70\% عند أعلى تركيز (10:1).

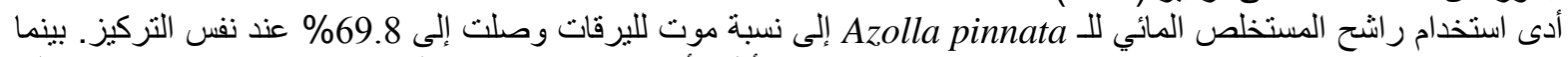
أظهر استخدام Anabaena flos aquae و Chlorella vulgaris أقل تأثثر في نسب موت اليرقات (52.1 و 40.1 \% أوضحت تحت تجارب الصوبة الإنتاجية أن جميع المعاملات أدت إلي تقليل تعداد النيماتودا في كل من التربة و الجذور. حيث أظهرت (التو الي).

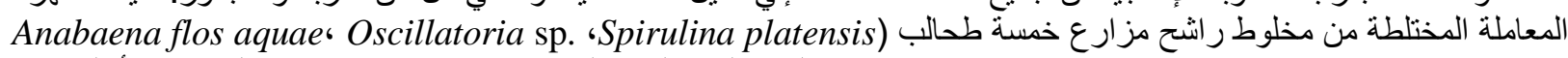
(Phormedium fragile Nostoc muscorum ،

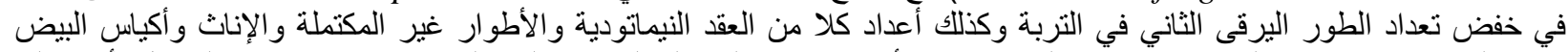

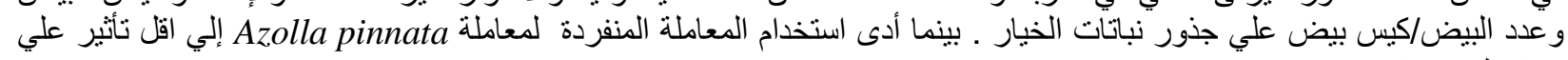
أدى استخدام جميع المعاملات خاصة المختلطة إلى حدوث زيادة في الوزن الغض للمجموع الخضري والجذور وكذلك زيادة محصول الخيار.

يمكن من هذه الدراسة التوصية باستخدام المعاملات البيو-عضوية لمكافحة نبماتودا تعقد الجذور في الخيار وخصوصاً تحت

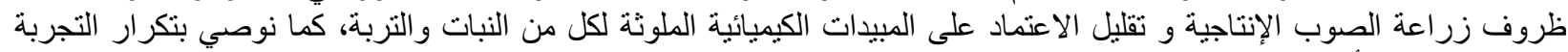

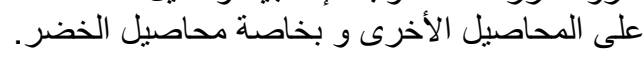

المجلة العلمية لكلية الزراعة - جامعة القاهرة - المجلد (60) العدد الرابع (أكتوبر 2009 ) : 443-459 . 